\title{
Implementasi Metode Multi-Objektive Optimization On The Basis Of Ratio Analysis Dalam Menentukan Tumbuh Kembang Balita
}

Comparison of the Implementation of Multi-Objective Optimization Method On The Basis Of Ratio Analysis In Toddler Growth

\author{
Ella Nuraini ${ }^{1}$, Muhammad Hari Ramadhan ${ }^{2}$, \\ ${ }^{I}$ Program Studi Sistem Informasi, Fakultas Teknik dan Ilmu Komputer \\ ${ }^{2}$ Dosen Jurusan Sistem Informasi Universitas Potensi Utama \\ ${ }^{1,2,}$ Universitas Potensi Utama, K.L. Yos Sudarso KM 6,5 No. 3A Tj. Mulia - Medan \\ Email :elanuraini674@gmail.com ${ }^{1}$ haryollezo@gmail.com ${ }^{2}$
}

\begin{abstract}
ABSTRAK
Rumah sakit wulan windi merupakan satu dari sekian Rumah sakit umum milik organisasi sosial Kota medan. Permasalahan yang dihadapi Rumah sakit umum wulan windy adalah sulitnya orang tua dan juga pihak rumah sakit dalam mengetahui perkembangan balita dan pemberian makanan sehat untuk penunjang pertumbuhan-pertumbuhan dan perkembangan pada anak usia 5-6 tahun kurang teratur. Permaslaahan ini dapat dipermudah dengan menggunakan sistem pendukung keputusan dan metode pengambilan keputusan yang tepat. Salah satunya metode pengambilan keputusan yang dapat digunakan adalah metode MOORA. Secara garis besar metode MOORA adalah metode yang memiliki perhitungan dengan kalkulasi yang minimum dan sangat sederhana. Metode ini memiliki tingkat selektifitas yang baik dalam menentukan suatu alternatif, semakin besar nilai yang dihasilkan, maka semkin utama pula untuk kembang balita yang terbaik. Perancangan sistem pendukung keputusan ini menggunakan model UML. Hasil dari penelitian ini adalah berbasis dekstop untuk sistem pendukung keputusan tumbuh kembang balita yang dibangun menggunakan bahasa pemograman disisi server PHP (Hypertext Preprocessor), pada basisdata menggunakan bahasa MySQL (My Structure Query Language).
\end{abstract}

Kata Kunci : Moora, Tumbuh kembang balita, Rumah sakit wulan windy, PHP dan MySQL

\section{ABSTRACT}

Wulan Windi Hospital is one of the public hospitals belonging to the Medan City social organization. The problems faced by the Wulan Windy General Hospital are the difficulty of parents and also the hospital in knowing the development of toddlers and providing healthy food to support growth and development in children aged 5-6 years less regularly. These problems can be facilitated by using decision support systems and appropriate decision-making methods. One of the decision-making methods that can be used is the MOORA method. Broadly speaking, the MOORA method is a method that has minimum calculations and is very simple. This method has a good level of selectivity in determining an alternative, the greater the value produced, the more likely it is for the best toddler development. The design of this decision support system uses the UML model. The results of this study are desktop-based for toddler growth and development decision support systems built using a programming language on the server side of PHP (Hypertext Preprocessor), on a database using MySQL (My Structure Query Language).

Keywords: Moora, Toddler growth and development, Wulan Windy Hospital, PHP and MySQL 


\section{PENDAHULUAN}

Rumah Sakit Umum Wulan Windy yaitu satu dari sekian Rumah Sakit Umum milik Organisasi Sosial Kota Medan yang berupa RSU, dikelola oleh Lainnya Perusahaan dan termaksud kedalam Rumah Sakit Umum D. Rumah Sakit Umum ini telah teregistrasi mulai 30/06/2015 dengan Nomor Surat Izin 442/46.11/II/2015 dan Tanggal Surat Izin 05/02/2015 dari KEPALA DINAS KESEHATAN KOTA MEDAN dengan Sifat Perpanjang, dan berlaku sampai 05 Februari 2015. Pemilihan makanan bayi 5 tahun adalah kegiatan untuk memilih makanan kepada bayi 5 tahun yang memenuhi kriteria pada Rumah Sakit ini. Dalam proses seleksi melibatkan kriteria yaitu, asupan gizi, pola makan, imunisasi, dan pola istirahat.

Namun, ada beberapa kendala yang dihadapi oleh Rumah Sakit Wulan Windy yaitu sulit nya orang tua dan pihak rumah sakit dalam mengetahui perkembangan balita, maka seharusnya orang tua dan pihak Rumah sakit wulan windy diharapkan dapat mempermudah dalam memberikan pengetahuan implementasi perkembangan balita dengan mengembangkan suatu teknologi yang mampu mengadopsi cara berfikir manusia yaitu tenologi Artificial Inteligence atau kecerdasan buatan.

Menurut Romadhon, Alfian, and Agus Sidiq Purnomo. "Sistem Pendukung Keputusan Untuk Menentukan Status Gizi Balita Menggunakan Metode Fuzzy, dengan adanya penentuan status gizi balita membantu dalam pertumbuhan bayi balita sehingga anak-anak dengan status gizi kurang mendapatkan penanganan yang lebih baik dan lebih cepat [1].

Menurut Muhammad Hari Ramadhan Dengan adanya sistem pendukung keputusan dalam menentukan siswa/i kurang mampu pada SD negeri 101785 deli serdang yang layak menerima bantuan operasional sekolah (BOS), dengan metode simple additive weighting (saw) maka memungkinkan peroses penentuan siswa/i kurang mampu dapat lebih mudah. Seperti halnya pada penelitian serupa dalam kosenp metode simple additive weighting (saw) yang judulnya adalah Rancangan Aplikasi Untuk Menganalisa Bus PT.Putra Pelangi Medan Dalam Menentukan Kondisi Mesin Yang Layak Untuk Diberangkatkan Dengan Menggunakan Metode SAW (Simple Additive Weighting). Dimana pada penelitian ini, PT.Putra Pelangi Medan sudah menjadi pilihan banyak masyarakat untuk bepergian ketempat tujuan. [2].

Menurut Samuel Manurung Metode Moora merupakan metode yang cocok untuk mendapatkan hasil yang baik di dalam sebuah seleksi terhadap Guru dan pegawai karena dapat mengolah data secara cepat dan tepat sesuai dengan yang diharapkan [3].

Menurut Muhammad Ashari, Arini, Fitri Mintarsih dalam Pemilihan Bibit Budidaya Ikan Air Tawar dengan Metode MOORA - Entropy, dengan menggunakan metode MOORA sebagai metode perangkingan dan metode Entropy sebagai pembobotan. Berdasarkan hasil uji kelayakan spk menggunakan prioritas kriteria dengan nilai suhu 0,222 , ph air 0,194 , kemudahan pakan 0,111 , minat masyarakat terhadap ikan 0,055 , oksigen terlarut 0,138 , ketinggian daratan 0,167 , lama ideal pembesaran ikan 0,027, dan luas kolam 0,083 menghasilkan ikan lele sebagai alternatif terbaik bibit budidaya ikan air tawar dengan nilai -0,1009 [4].

Menurut Sari, Ria Eka, and Alfa Saleh dengan menggunakan sistem penunjang keputusan (SPK) Sistem Penunjang Keputusan untuk Kinerja Pemilihan Dosen Berprestasi bisa di jadikan dasar pengambilan keputusan dalam proses Penilaian Kinerja Pemilihan Dosen Berprestasi [5].

Menurut Muhammad Fauzi dalam penelitian implementasi gap profile matching pada sistem pendukung keputusan dalam menentukan kenaikan level pada karyawan pt. long sun Indonesia Sistem Pendukung Keputusan mampu memecahkan suatu masalah dengan baik salah satunya pemilihan karyawan yang layak dalam menerima kenaikan level [6].

Menurut Evri Ekadiansyah Dengan adanya Sistem Penunjang Keputusan ini dapat membantu pimpinan dalam pengambilan keputusan kenaikan golongan pegawai secara mudah sehingga dapat memaksimalkan dan mengoptimalkan keputusan, sehingga dapat meminimalisasi kesalahan dalam pengambilan keputusan [7].

Menurut Fitriana Harahap Dengan adanya sistem pendukung keputusan ini maka pihak sekolah akan lebih mudah dalam pengambilan keputusan untuk menentukan peserta siswa studi banding karena aplikasi ini lebih mudah dibandingkan sistem yang lama dan penyimpanan datanya lebih akurat. Dari hasil penelitian menunjukkan pemanfaatan Weighted Product sebagai model sistem pendukung keputusan penentuan peserta siswa studi banding dapat memudahkan dalam 
menentukan siswa yang berhak ikut studi banding dengan pembobotan multikriteria dan seleksi dengan lebih cepat, cermat dan lebih efektif [8].

\section{METODELOGI PENELITIAN}

2.1. Metode Pengumpulan Data

Berikut ini adalah beberapa teknik pengumpulan data yang peneliti lakukan untuk melengkapi bahan penelitian :

a. Tahap Analisa Kebutuhan

Peneliti melakukan penelitian ke Rumah sakit wulan windy untuk mendapatkan data-data yang diperlukan.

b. Tanya Jawab, Peneliti melakukan tanya jawab kepada Bapak dr. Dermawan, Sp.A pada bagian penyakit Anak untuk mendapatkan penjelasan dari masalah yang sebelumnya kurang jelas yaitu tentang mekanisme sistem yang digunakan dan juga untuk meyakinkan bahwa data yang diperoleh dikumpulkan benar-benar akurat.

c. Sampel, Peneliti melakukan pengumpulan sampel penelitian yang berguna untuk penelitian ini.

d. Pustaka, Peneliti menggunakan buku, jurnal dan karya ilmiah sebagai referensi dan landasan teori pada penelitian ini. Penelitian ini akan melalui beberapa tahapan. Tahapan dalam penelitian ini dapat di modelkan pada diagram Waterfall. Adapun beberapa tahapan yang digunakan dalam penelitian ini dapat dilihat pada gambar 1 .

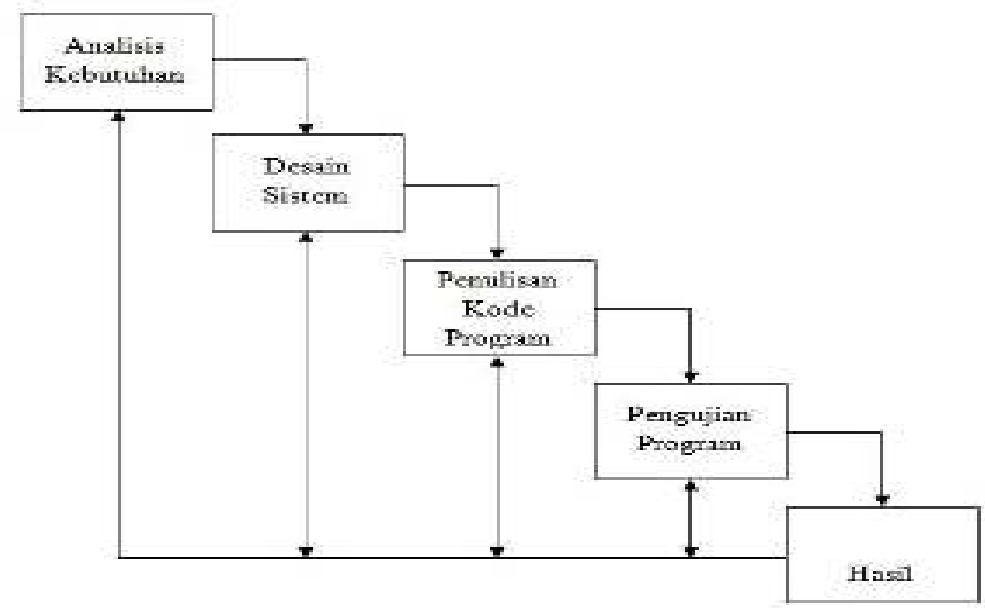

Gambar 1. Diagram Waterfall Pengembangan Sistem

Pengembangan sistem menggunakan Waterfall diagram dapat dijelaskan sebagai berikut :

1. Analisis Kebutuhan

Observasi/Pengamatan Langsung Peneliti melakukan observasi/mengamati langsung ke Rumah sakit wulan windy yaitu mengamati tumbuh kembang balita untuk mendapatkan data-data yang dibutuhkan.

2. Desain Sistem

Rancangan sistem yang peneliti gunakan adalah pemodelan UML yaitu use case diagram, class diagram, activity diagram dan sequence diagram dilengkapi perancangan tampilan (layout) dari sistem yang akan dibangun.

3. Penulisan Kode Program

Penulisan kode program menggunakan bahasa pemrograman $P H P$ dan menggunakan database MySQL.

4. Pengujian Program

Pengujian program menggunakan pemrograman $P H P$ dan pengujian teori menggunakan blackbox testing pengujian yang dilakukan hanya mengamati hasil eksekusi melalui data uji dan memeriksa fungsional dari perangkat lunak. 
5. Hasil

Pada tahapan ini peneliti telah menyelesaikan Perbandingan Implementasi Metode MultiObjektive Optimization On The Basis Of Ratio Analysis Dalam Menentukan Tumbuh Kembang Balita (Studi Kasus: Rumah sakit wulan windy).

\section{HASIL DAN PEMBAHASAN}

\subsection{Desain Sistem Pemodelan UML (Unifield Modeling Language)}

Desain sistem yang peneliti gunakan adalah pemodelan Unified Modeling Language (UML). Berikut ini adalah beberapa pemodelan Unified Modeling Language (UML) yang peneliti gunakan :

1. Use Case Diagram

Use case diagram implementasi metode MOORA dalam menentukan tumbuh kembang balita (studi kasus : Rumah sakit wulan windy) dapat di lihat pada gambar 2.

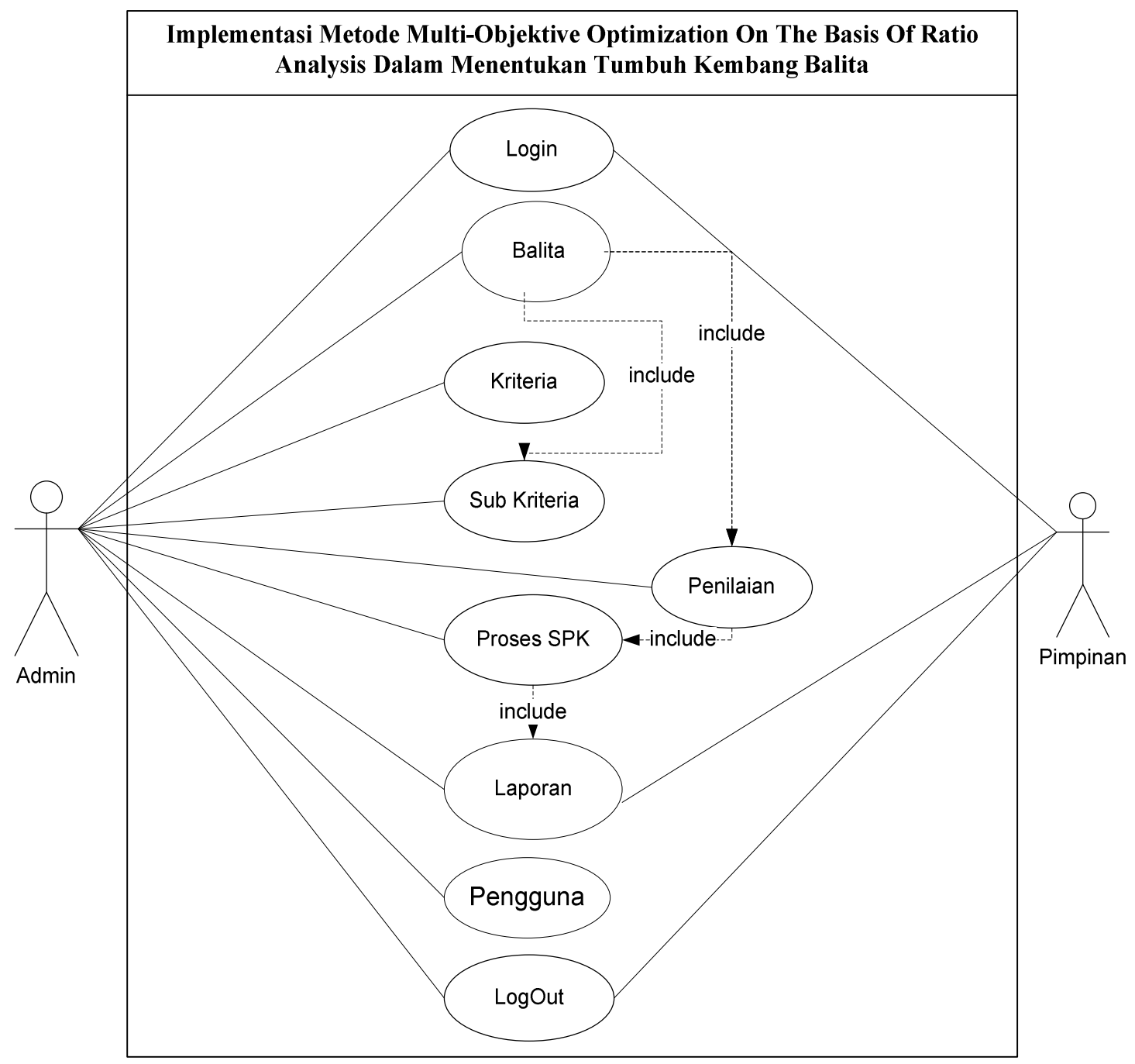

Gambar 2 Use Case Diagram

2. Class Diagram

Class Diagram implementasi metode multi-objective optimization on the basis of ratio analysis dalam tumbuh kembang balita (studi kasus : Rumah sakit wulan windy) dapat di lihat pada Gambar 3. Sebagai berikut : 


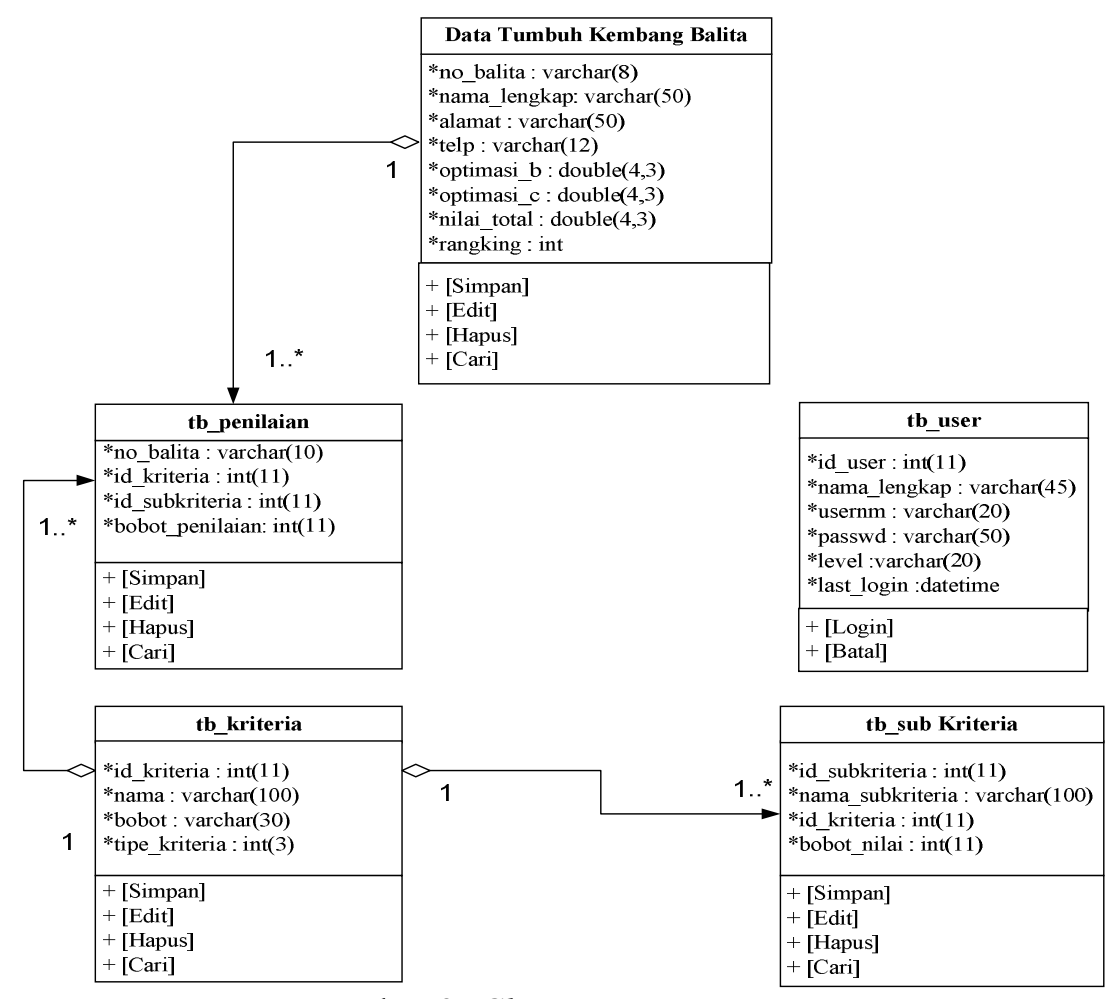

Gambar 3. Class Diagram

3. Activity Diagram Diagram Data tumbuh kembang balita merupakan Activity Diagram data tumbuh kembang balita dari Aplikasi implementasi metode multi-objective optimization on the basis of ratio analysis dalam menentukan tumbuh kembang balita (studi kasus : Rumah sakit wulan windy).

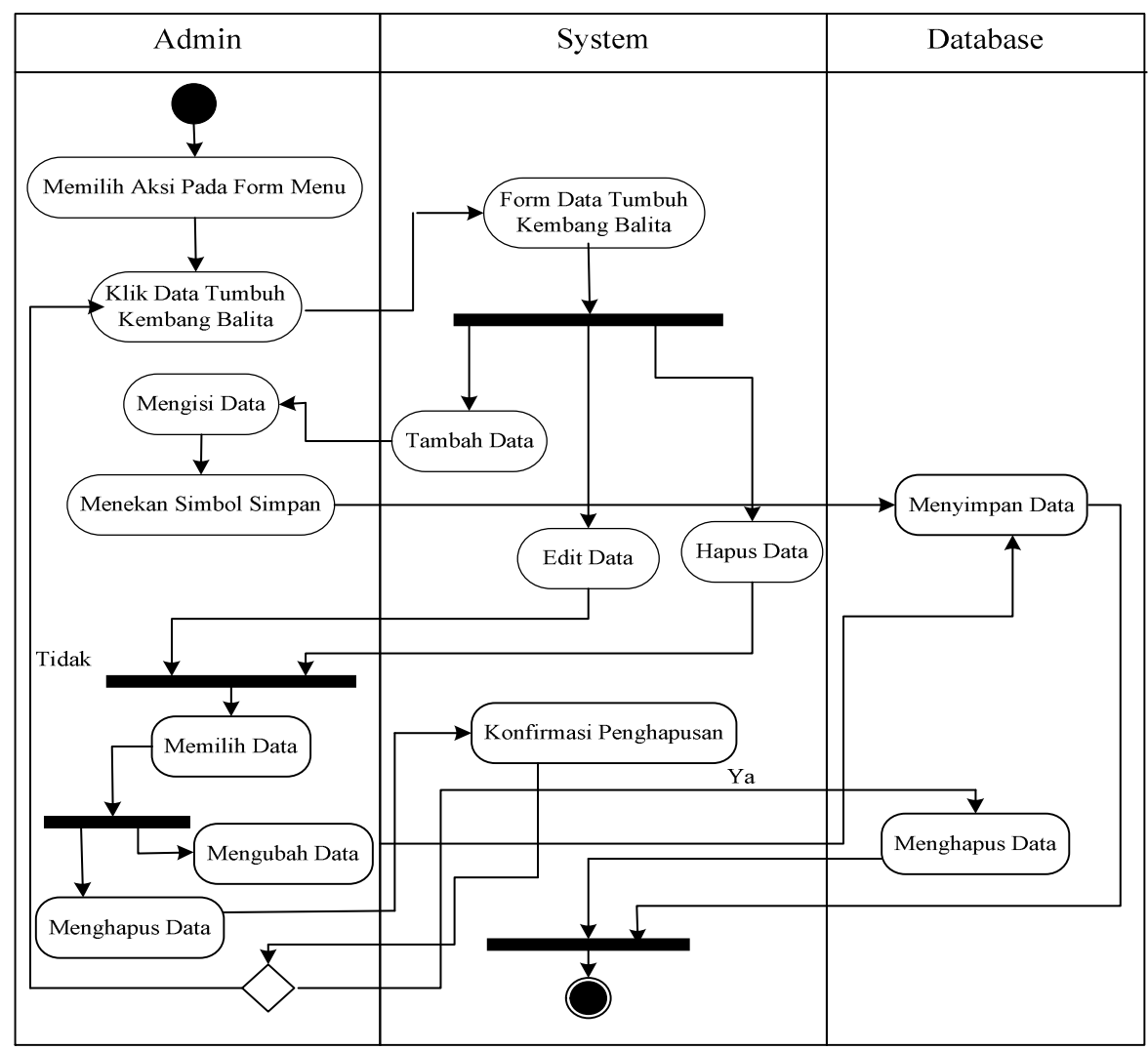

Gambar 4. Activity Diagram 
4. Sequence Diagram Data tumbuh kembang balita merupakan Sequence Diagram Data tumbuh kembang balita Aplikasi implementasi metode multi-objective optimization on the basis of ratio analysis dalam tumbuh menentukan kembang balita (Studi Kasus : Rumah sakit wulan windy).

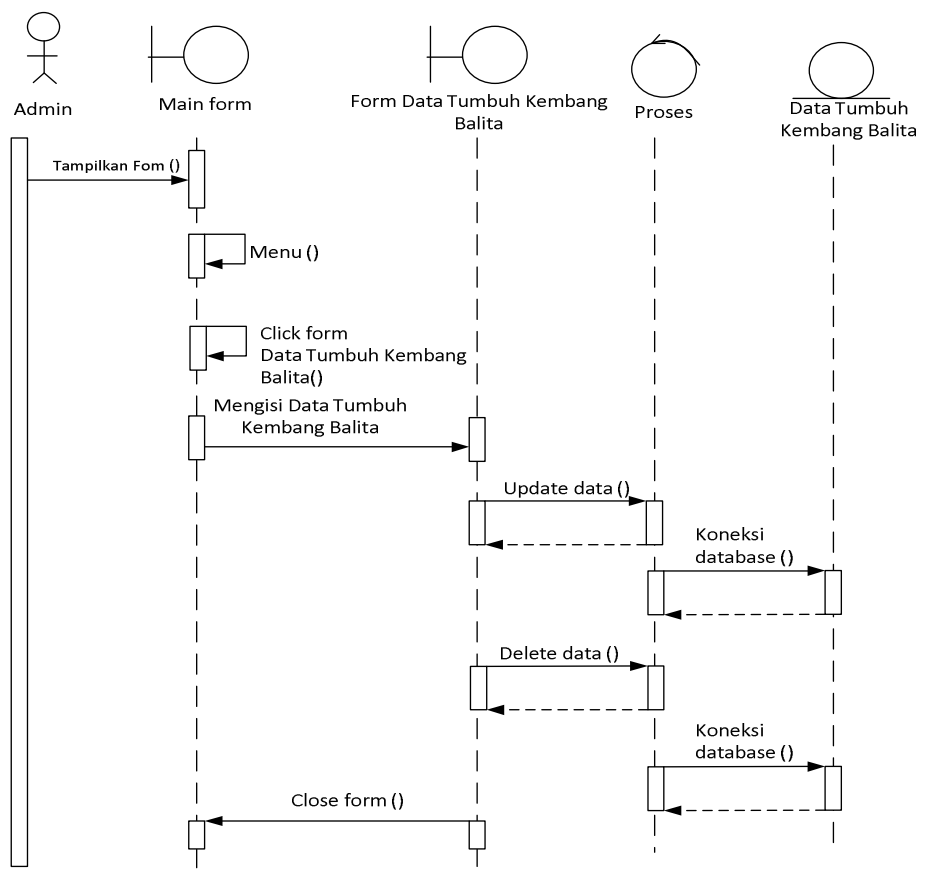

Gambar 5. Sequence Diagram

\subsection{Penerapan Metode}

Langkah-langkah penerapan metode MOORA dalam SPK pemilihan tumbuh kembang balita terbaik dapat digambarkan dalam bentuk flowchart sebagai berikut :

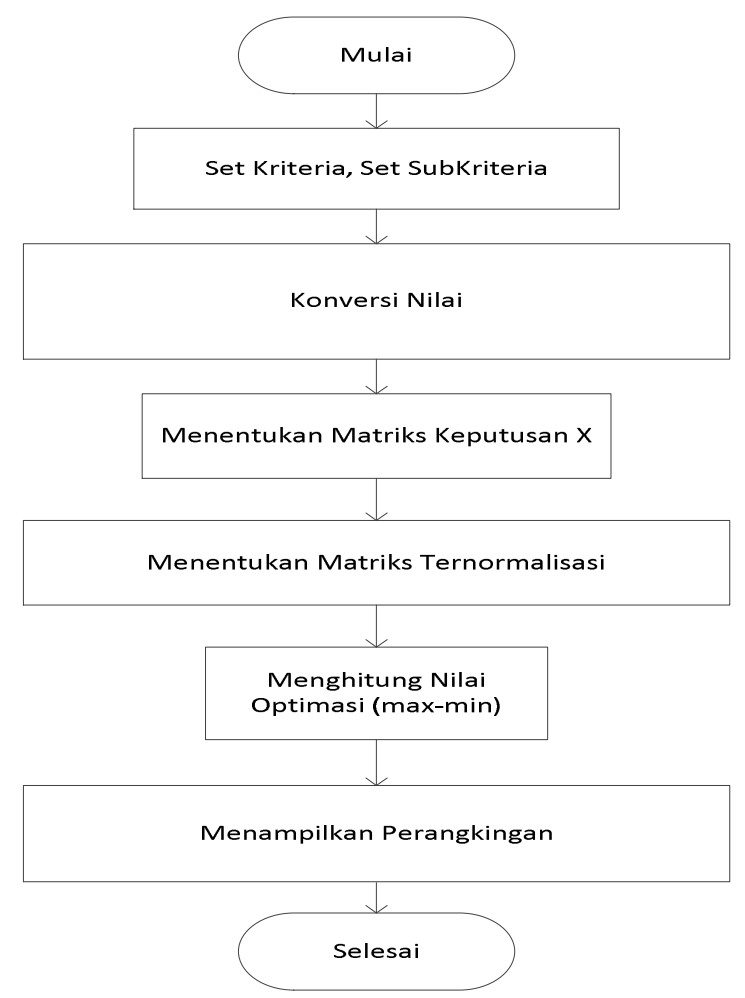

Gambar 6. Flowchart Algoritma MOORA. 
berikut :

Sesuai dengan flowchart pada gambar diatas, maka dapat dijelaskan tahapannya sebagai

1. Set Kriteria

Kriteria yang menjadi pengujian yaitu asupan gizi, pola makan, imunisasi, dan pola istirahat. Adapun bobot setiap kriteria ditentukan berdasarkan kebijakan dari pihak perusahaan. Tabel.1 berikut ini merupakan kriteria dan bobot yang telah ditentukan oleh pihak perusahaan.

Tabel 1 Kriteria Tumbuh Kembang Balita

\begin{tabular}{|c|l|c|}
\hline Kode Kriteria & \multicolumn{1}{|c|}{ Nama Kriteria } & Bobot \\
\hline 1 & Asupan Gizi & $40 \%$ \\
\hline 2 & Pola Makan & $30 \%$ \\
\hline 3 & Imunisasi & $20 \%$ \\
\hline 4 & Pola Istirahat & $10 \%$ \\
\hline
\end{tabular}

2. Set Subkriteria

Subkriteria merupakan bagian dari setiap kriteria yang digunakan untuk penilaian. Setiap kriteria memiliki beberapa subkriteria yang dapat dijelaskan sebagai berikut :

a. Asupan Gizi

Subkriteria dari asupan gizi dapat dilihat pada tabel 2.

Tabel 2 Asupan Gizi

\begin{tabular}{|c|c|c|}
\hline Hasil & Bobot & Keterangan \\
\hline$<50 \%$ & 1 & Kurang Baik \\
\hline $50-70$ & 2 & Cukup \\
\hline $71-85$ & 3 & Baik \\
\hline $86-100$ & 4 & Sangat Baik \\
\hline
\end{tabular}

b. Pola Makan

Subkriteria dari pola makan dapat dilihat pada tabel 3 .

Tabel 3 Pola Makan

\begin{tabular}{|c|c|}
\hline Objek & Bobot \\
\hline Sangat Baik & 4 \\
\hline Baik & 3 \\
\hline Cukup & 2 \\
\hline Buruk & 1 \\
\hline
\end{tabular}

c. Imunisasi

Subkriteria dari imunisasi dapat dilihat pada tabel 4 .

Tabel 4.Imunisasi

\begin{tabular}{|c|c|}
\hline Objek & Bobot \\
\hline Sangat Baik & 4 \\
\hline Baik & 3 \\
\hline Cukup & 2 \\
\hline Buruk & 1 \\
\hline
\end{tabular}

d. Pola Istirahat

Subkriteria dari pola istirahat dapat dilihat pada tabel 5.

Tabel 5.Pola Istirahat

\begin{tabular}{|c|c|}
\hline Objek & Bobot \\
\hline Sangat Baik & 4 \\
\hline
\end{tabular}




\begin{tabular}{|c|c|}
\hline Baik & 3 \\
\hline Cukup & 2 \\
\hline Buruk & 1 \\
\hline
\end{tabular}

3. Alternatif

Alternatif untuk memberikan penilaian terhadap tumbuh kembang balita berdasarkan kriteria yang telah ditentukan. Data tumbuh kembang balita yang akan dinilai dapat dilihat pada tabel 6 berikut ini.

Tabel 6 Data Alternatif

\begin{tabular}{|c|c|c|c|c|c|}
\hline No & Nama Balita & Asupan Gizi & Pola Makan & Imunisasi & Pola Istirahat \\
\hline M001 & Lian & $75 \%$ & Baik & Baik & Cukup \\
\hline M002 & Ayu & $60 \%$ & Buruk & Sangat Baik & Cukup \\
\hline M003 & Bill & $80 \%$ & Baik & Cukup & Buruk \\
\hline M004 & Andrea & $70 \%$ & Baik & Sangat Baik & Baik \\
\hline M005 & Theresia & $87 \%$ & Buruk & Baik & Sangat Baik \\
\hline
\end{tabular}

4. Konversi nilai tumbuh kembang balita

Data penilaian tumbuh kembang balita selanjutnya dikonversi nilai setiap kriteriannya dalam bentuk bobot nilai seperti pada tabel 7 berikut.

Tabel 7. Data Bobot Penilaian

\begin{tabular}{|c|c|c|c|c|c|}
\hline No & Nama Balita & Asupan Gizi & Pola Makan & Imunisasi & Pola Istirahat \\
\hline M001 & Lian & 3 & 3 & 3 & 2 \\
\hline M002 & Ayu & 2 & 1 & 4 & 2 \\
\hline M003 & Bill & 3 & 3 & 2 & 1 \\
\hline M004 & Andrea & 2 & 3 & 4 & 3 \\
\hline M005 & Theresia & 4 & 1 & 3 & 4 \\
\hline
\end{tabular}

5. Matriks Keputusan

Membuat matrik keputusan xij berdasarkan tabel 8 sebagai berikut:

$$
X=\left[\begin{array}{llll}
3 & 3 & 3 & 2 \\
2 & 1 & 4 & 2 \\
3 & 3 & 2 & 1 \\
2 & 3 & 4 & 3 \\
4 & 1 & 3 & 4
\end{array}\right]
$$

6. Menentukan matrik yang dinormalisasi dengan menggunakan rumus :

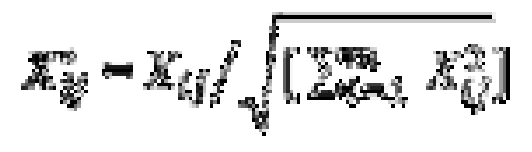

Adapun langkah-langkah perhitungannya adalah sebagai berikut:

$$
\begin{aligned}
X_{11} & =\frac{3}{\sqrt{3^{2}+2^{2}+3^{2}+2^{2}+4^{2}}} \\
& =\frac{3}{\sqrt{42}}=\frac{3}{6,48} \\
& =0,463 \\
X_{21} & =\frac{2}{\sqrt{3^{2}+2^{2}+3^{2}+2^{2}+4^{2}}}
\end{aligned}
$$




$$
\begin{aligned}
& =\frac{2}{\sqrt{42}}=\frac{2}{6,48} \\
& =11,3114 \\
& X_{31}=\frac{3}{\sqrt{3^{2}+2^{2}+3^{2}+2^{2}+4^{2}}} \\
& =\frac{3}{\sqrt{42}}=\frac{3}{6,48} \\
& =4,463 \\
& X_{41}=\frac{2}{\sqrt{3^{2}+2^{2}+3^{2}+2^{2}+4^{2}}} \\
& =\frac{2}{\sqrt{42}}=\frac{2}{6,48} \\
& 0.309 \\
& X_{51}=\frac{4}{\sqrt{3^{2}+2^{2}+3^{2}+2^{2}+4^{2}}} \\
& -\frac{4}{\sqrt{42}}-\frac{4}{6,48} \\
& \text { 0. } 61 \text { ? } \\
& X_{12}=\frac{3}{\sqrt{3^{2}+1^{2}+3^{2}+3^{2}+1}} \\
& =\frac{3}{\sqrt{29}}-\frac{3}{5,385} \\
& =0,557 \\
& \mathrm{X}_{22}=\frac{1}{\sqrt{3^{2}+1^{2}+3^{2}+3^{2}+1}} \\
& =\frac{1}{\sqrt{29}}=\frac{1}{5,385} \\
& \text { = 1). } 1 \times 6 \\
& X_{32}=\frac{3}{\sqrt{3^{2}+1^{2}+3^{2}+3^{2}+1}} \\
& =\frac{3}{\sqrt{29}}=\frac{3}{5,385} \\
& =0.55 \% \\
& X_{42}=\frac{3}{\sqrt{3^{2}+1^{2}+3^{2}+3^{2}+1}} \\
& =\frac{3}{\sqrt{29}}=\frac{3}{5,385} \\
& =0,557 \\
& X_{52}=\frac{1}{\sqrt{3^{2}+1^{2}+3^{2}+3^{2}+1}} \\
& -\frac{1}{\sqrt{29}}-\frac{1}{5,385} \\
& =0,186 \\
& X_{13}=\frac{3}{\sqrt{3^{2}+4^{2}+2^{2}+4^{2}+3^{2}}} \\
& =\frac{3}{\sqrt{54}}=\frac{3}{7,348} \\
& =0,40 \mathrm{~K} \\
& X * \frac{4}{\sqrt{3^{2}+4^{2}+2^{2}+4^{2}+3^{2}}} \\
& =\frac{4}{\sqrt{54}}=\frac{4}{7,348} \\
& =0,544 \\
& x_{i:} \quad-\frac{2}{\sqrt{3^{2}+4^{2}+2^{2}+4^{2}+3^{2}}} \\
& =\frac{2}{\sqrt{54}}=\frac{2}{7,348} \\
& 0.272 \\
& x_{-}=\frac{4}{\sqrt{3^{2}+4^{2}+2^{2}+4^{2}+3^{2}}} \\
& -\frac{4}{\sqrt{54}}-\frac{4}{7,348} \\
& 0.544 \\
& \frac{3}{\sqrt{54}} \frac{3}{7,348} \\
& =0.10 \mathrm{~K} \\
& X_{14}=\frac{2}{\sqrt{2^{2}+2^{2}+1^{2}+3^{2}+4^{2}}} \\
& =\frac{2}{\sqrt{34}}=\frac{2}{5,83} \\
& =0.343 \\
& x_{2} \quad \frac{2}{\sqrt{2^{2}+2^{2}+1^{2}+3^{2}+4^{2}}} \\
& =\frac{2}{\sqrt{34}}=\frac{2}{5,83} \\
& =11,343 \\
& \text { X) } \quad \frac{1}{\sqrt{2^{2}+2^{2}+1^{2}+3^{2}+4^{2}}} \\
& =\frac{1}{\sqrt{34}}=\frac{1}{5,83} \\
& =0,171 \\
& X_{44}=\frac{3}{\sqrt{2^{2}+2^{2}+1^{2}+3^{2}+4^{2}}} \\
& =\frac{3}{\sqrt{34}}-\frac{3}{5,83} \\
& =0,514 \\
& X_{54}=\frac{4}{\sqrt{2^{2}+2^{2}+1^{2}+3^{2}+4^{2}}}
\end{aligned}
$$

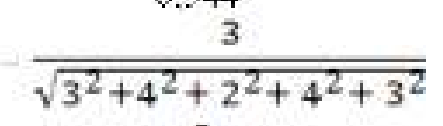




$$
\begin{aligned}
& =\frac{4}{\sqrt{34}}=\frac{4}{5,83} \\
& =0,686
\end{aligned}
$$

Hasil perhitungan dari normalisasi matrik $\mathrm{X} * \mathrm{ij}$ adalah :

$$
y=\left[\begin{array}{llll}
0,463 & 0.557 & 0,408 & 0,343 \\
0,309 & 0,186 & 0,544 & 0,343 \\
0,463 & 0.557 & 0,272 & 0,171 \\
0,309 & 0,557 & 0,544 & 0,514 \\
0,617 & 0,186 & 0,408 & 0,686
\end{array}\right]
$$

7. Menghitung nilai optimasi ( $\max -\min )$

Setelah hasil perhitungan dari normalisasi matrik $\mathrm{X} * \mathrm{ij}$ didapatkan dilanjutkan dengan menghitung matriks normalisasi terbobot

$$
\begin{array}{ll} 
& y i=\sum_{j=1}^{g} w_{f} x_{i j}^{*}-\sum_{j=9+1}^{n} w_{f} x_{i f}^{*} \\
\mathrm{Wj}_{1,1}=0,4 * 0,463 & =0,185 \\
\mathrm{Wj}_{1,2}=0,3 * 0,557 & =0,167 \\
\mathrm{Wj}_{1,3}=0,2 * 0,408 & =0,082 \\
\mathrm{Wj}_{1,4}=0,1 * 0,343 & =0,034 \\
\mathrm{Wj}_{2,1}=0,4 * 0,309 & =0,124 \\
\mathrm{Wj}_{2,2}=0,3 * 0,186 & =0,056 \\
\mathrm{Wj}_{2,3}=0,2 * 0,544 & =0,109 \\
\mathrm{Wj}_{2,4}=0,1 * 0,343 & =0,034 \\
\mathrm{Wj}_{3,1}=0,4 * 0,463 & =0,185 \\
\mathrm{Wj}_{3,2}=0,3 * 0,557 & =0,167 \\
\mathrm{Wj}_{3,3}=0,2 * 0,272 & =0,054 \\
\mathrm{Wj}_{3,4}=0,1 * 0,171 & =0,017 \\
\mathrm{Wj}_{4,1}=0,4 * 0,309 & =0,124 \\
\mathrm{Wj}_{4,2}=0,3 * 0,557 & =0,167 \\
\mathrm{Wj}_{4,3}=0,2 * 0,544 & =0,109 \\
\mathrm{Wj}_{4,4}=0,1 * 0,514 & =0,051 \\
\mathrm{Wj}_{5,1}=0,4 * 0,617 & =0,247 \\
\mathrm{Wj}_{5,2}=0,3 * 0,186 & =0,056 \\
\mathrm{Wj}_{5,3}=0,2 * 0,408 & =0,082 \\
\mathrm{Wj}_{5,4}=0,1 * 0,686 & =0,069
\end{array}
$$

Hasilnya dapat dilihat pada matrik berikut :

$$
\mathrm{X}=\left[\begin{array}{lllll}
0,185 & 0,167 & 0,082 & 0,034 \\
0.124 & 0,056 & 0,109 & 0,034 \\
0,185 & 0,167 & 0,054 & 0,017 \\
0,124 & 0,167 & 0,109 & 0,051 \\
0,247 & 0,056 & 0,082 & 0,069
\end{array}\right]
$$

Setelah hasil normalisasi terbobot didapatkan dilanjutkan dengan menghitung nilai optimasi (Max-Min) :

$$
\begin{aligned}
\mathrm{W} 1 & =\left(\mathrm{X}_{1,1}+\mathrm{X}_{1,2}+\mathrm{X}_{1,3}+\mathrm{X}_{1,4}\right)-(0) \\
& =0,185+0,167+0,082+0,034
\end{aligned}
$$




$$
\begin{aligned}
& =0,468 \\
\mathrm{~W} 2 & =\left(X_{2,1}+X_{2,2}+X_{2,3}+X_{2,4}\right)-(0) \\
& =0,124+0,056+0,109+0,034 \\
& =0,322 \\
\mathrm{~W} 3 & =\left(X_{3,1}+X_{3,2}+X_{3,3}+X_{3,4}\right)-(0) \\
& =0,185+0,167+0,054+0,017 \\
& =0,424 \\
\mathrm{~W} 4 & =\left(X_{4,1}+X_{4,2}+X_{4,3}+X_{4,4}\right)-(0) \\
& =0,124+0,167+0,109+0,051 \\
& =0,451 \\
\mathrm{~W} 5 & =\left(X_{5,1}+X_{5,2}+X_{5,3}+X_{5,4}\right)-(0) \\
& =0,247+0,056+0,082+0,069 \\
& =0,453
\end{aligned}
$$

8. Perangkingan nilai Yi

Alternatif terbaik adalah alternative yang memiliki nilai optimasi tertinggi. Hasil dari penghitungan nilai optimasi dan pemeringkatan alternatif ditunjukkan pada Tabel 9 berikut.

Tabel 9. Hasil Perankingan Nilai Optimasi ( Max-Min )

\begin{tabular}{|c|c|c|c|}
\hline Kode & Alternatif & TOTAL & Rangking \\
\hline M001 & Lian & 0,468 & 1 \\
\hline M005 & Theresia & 0,453 & 2 \\
\hline M004 & Andrea & 0,451 & 3 \\
\hline M003 & Bill & 0,424 & 4 \\
\hline M002 & Ayu & 0,322 & 5 \\
\hline
\end{tabular}

Maka hasil dari analisis tumbuh kembang balita terbaik pada Rumah Sakit Umum Wulan Windy menggunakan metode MOORA yang mendapatkan nilai tertinggi ialah Lian.

\subsection{Tampilan Hasil}

Berikut ini akan dijelaskan tentang tampilan hasil implementasi metode multi-objective optimization on the basis of ratio analysis dalam menentukan tumbuh kembang balita yang dapat dilihat sebagai berikut :

1. Tampilan Form Data Kriteria

Tampilan pada Form Data Kriteria pada aplikasi yang telah dibuat dapat dilihat pada gambar 7 .

Sebagai berikut :

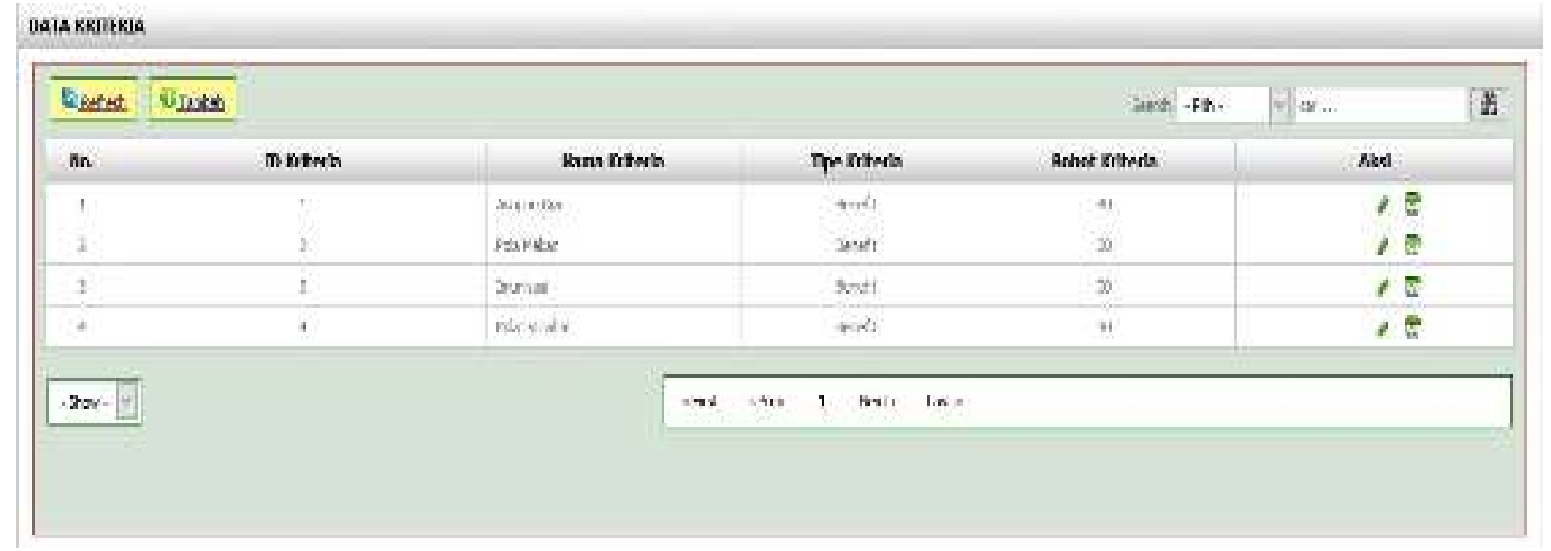

Gambar 7. Tampilan Form Data Kriteria

\section{Tampilan Form Sub Kriteria}

Tampilan pada Form Sub Kriteria pada aplikasi yang telah dibuat dapat dilihat pada gambar 8 .

Sebagai berikut : 


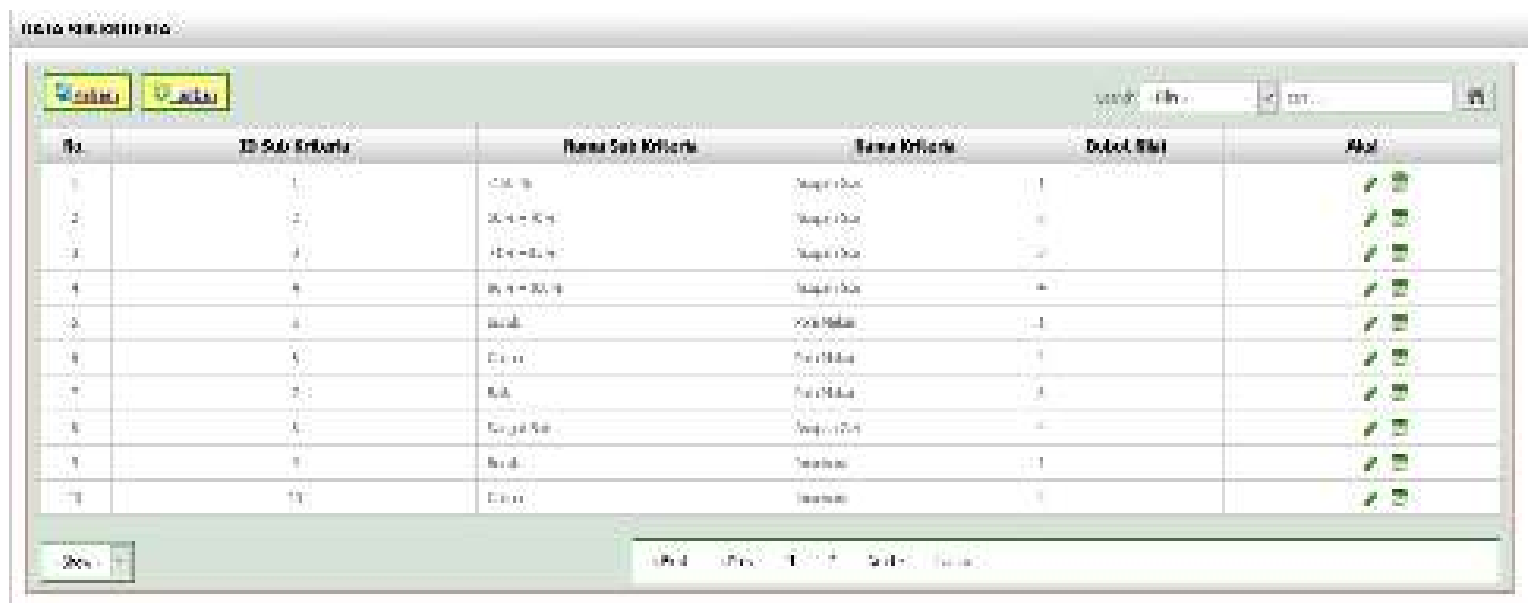

Gambar 8. Tampilan Form Sub Kriteria

\section{KESIMPULAN}

Berdasarkan perumasan masalah yang telah didapatkan maka dapat diambil beberapa kesimpulan sebagai berikut :

1. Sistem penentuan tumbuh kembang balita dapat membantu dalam pengambilan keputusan dalam menganalisa masalah pertumbuhan balita pada rumah sakit umum wulan windy .

2. Metode MOORA dapat digunakan sebagai sebuah alat bantu untuk melakukan penilaian Tumbuh Kembangan Balita secara tepat dan akurat sesuai dengan ketentuan/kriteria dan dapat dijadikan dasar dalam menentukan keputusan secara lebih rasional.

3. Sistem Pendukung Keputusan ini menggunakan metode MOORA dimana hasil akhir dari proses pendukung penentuan Tumbuh Kembangan Balita ini adalah menghasilkan nilai prefensi hasil perhitungan metode MOORA. Alternatif terbaik adalah alternative yang memiliki nilai optimasi tertinggi. Hasil dari penghitungan nilai optimasi dan pemeringkatan alternatif.

\section{SARAN}

Berdasarkan kekurangan sistem dan hasil penelitian maka peneliti memberikan beberapa saran untuk pengembangan selanjutnya yaitu :

1. Sebaiknya sistem yang dibuat diterapkan pada perangkat android.

2. Sebaiknya sistem yang dibuat dapat diterapkan pada semua jenis sistem operasi.

3. Sebaiknya Aplikasi ini dapat dikembangkan dengan cara dikomparasikan menggunakan metode lain seperti metode Analitycal Hierarchy Process atau Simple Additive Weighting, sehingga dapat dilihat keakuratan datanya.

\section{UCAPAN TERIMA KASIH}

Penulis mengucapkan terima kasih yang sebesar-besarnya kepada Universitas Potensi Utama yang telah membantu penulis dalam menyelesaikan laporan penelitian ini.

\section{DAFTAR PUSTAKA}

[1] Romadhon, A., \& Purnomo, A. S. (2016). Sistem Pendukung Keputusan Untuk Menentukan Status Gizi Balita Menggunakan Metode Fuzzy Inferensi Sugeno (Berdasarkan Metode Antropometri). INFORMAL: Informatics Journal, 1(3), 78-87. 
[2] Ramadhan, M. H. (2017, October). RANCANGAN APLIKASI UNTUK MENGANALISA BUS PT. PUTRA PELANGI MEDAN DALAM MENENTUKAN KONDISI MESIN YANG LAYAK UNTUK DIBERANGKATKAN DENGAN MENGGUNAKAN METODE SAW (SIMPLE ADDITIVE WEIGHTING). In Seminar Nasional Informatika (SNIf) (Vol. 1, No. 1, pp. 413-418).

[3] Manurung, S. (2018). Sistem Pendukung Keputusan Pemilihan Guru dan Pegawai Terbaik Menggunakan Metode MOORA. Simetris: Jurnal Teknik Mesin, Elektro dan Ilmu Komputer, 9(1), 701-706.

[4] Ashari, M., \& Arini, F. M. (2017). Aplikasi Pemilihan Bibit Budidaya Ikan Air Tawar dengan Metode MOORA-Entropy. Query: Journal of Information Systems, 1(2).

[5] Sari, R. E., \& Saleh, A. (2017, October). Penilaian kinerja dosen dengan menggunakan metode AHP (Studi kasus: di STMIK Potensi Utama Medan). In Seminar Nasional Informatika (SNif) (Vol. 1, No. 1, pp. 108-114).

[6] Fauzi, M. (2017, November). implementasi gap profile matching pada sistem pendukung keputusan dalam menentukan kenaikan level pada karyawan pt. long sun Indonesia. In Seminar Nasional Informatika (SNIf) (Vol. 1, No. 1, pp. 166-171).

[7] Ekadiansyah, E. (2014, September). PERANCANGAN SISTEM PENDUKUNG KEPUTUSAN DENGAN METODE BOBOT UNTUK MENILAI KENAIKAN GOLONGAN PEGAWAI. Seminar Nasional Informatika.

[8] Harahap, F. (2017, November). PENERAPAN METODE WEIGHTED PRODUCT PADA SISTEM PENDUKUNG KEPUTUSAN SELEKSI PESERTA SISWA STUDI BANDING. In Seminar Nasional Informatika (SNIf) (Vol. 1, No. 1, pp. 265-270). 